\title{
Icebreakers at War: Flight of the Russian White Government from Archangel (19-25 February 1920)
}

\section{George Bolotenko}

En 1919, dès que les puissances interventionnistes en Russie ont compris que les bolchéviks allaient gagner, elles se sont mises à retirer leurs forces. Par conséquent, les gouvernements blancs de diverses régions, certaines formations militaires et de nombreux civils ont aussi choisi de quitter les lieux. Cet article traite d'une des évacuations, du port d'Arkhangelsk sur la mer Blanche en février 1920. Ce cas présente un intérêt parce que l'évacuation s'est déroulée sur un brise-glace, le Minin, lors d'une poursuite par un autre brise-glace, le Kanada (anciennement le Earl Grey, navire du gouvernement canadien). Les deux navires ont participé à des combats maritimes juste au sud du cercle polaire, probablement le seul événement de ce genre dans l'histoire maritime.

\section{Introduction}

The story told here is part of a larger historical phenomenon, the flight of White administrations, armies, military families and civilians out of Red Russia. As Red armies established control over the heartland, White opposition forces were pushed to the littorals, and eventually into flight. With some differences among them these departures more or less followed a similar pattern. The evacuations occurred on the eve of Red forces breaking through last lines of White defence; wounded and rear guard units were, willingly or not, left behind, as well as thousands of civilians; the ports of departure became scenes of chaos, disorder and desperation; people of influence and money found ways to assure a place aboard ship; anything that could float was utilized in these evacuations.

The first occurred in Odessa, when the French occupying forces left the city in April of 1919, taking with them some thousands of White military and

The Northern Mariner / Le marin du nord, XXX, No. 2 (Summer 2020), 113-132 
administration officials, but also abandoning rear guard units and others wishing to leave. Next came Archangel - the story told below - in February of 1920. General Denikin's armies left Novorossiisk in March of 1920 largely on Allied warships, a disastrous, chaotic evacuation, leaving behind half his army (35,000 men). The flight from Crimea in November 1920 was much better organized by General Wrangel, with designated army units falling back to designated ports (Sevastopol, Evpatoriia, Yalta, Feodosiia and Kerch), boarding according to schedule and then putting out. He saved most of his army and their families; approximately 150,000 people sailed away on 140 or so vessels. The last major flight was out of Vladivostok in October 1922, when General Dikhters and Admiral Stark led away 10,000 people on approximately forty ships of various sizes, an epic voyage ending in Manila, in the Philippines, in August of that year.

Much debate continues about these evacuations and responsibility for those abandoned. Generally it is held that Wrangel's evacuation from the Crimea was best managed. However, even there, a hellish panic seized the embarkation ports, the fear of being left behind. Some contemporaries described the last days in the Crimean ports as "end-time," and declared that "judgement Day had come" as fires blazed away and all sorts of excesses were committed by those left behind. Understandably, perhaps, because a hellish fate awaited those abandoned (even Wrangel left behind, by some counts, 80,000 people desperate to leave, largely civilian but also military). And the abandoned had reason to fear, for in all these ports, scores immediately "were settled" by the victorious Reds. In the Crimea alone, 30,000 were executed in only the several months following capture of the peninsula by the Reds.

What follows is the narrative of the White flight from Archangel, unique because of the role of icebreakers in this flight - and one of these was the Kanada, formerly the Canadian icebreaker Earl Grey.

*** $*$

In the evening of 19 February 1920 the Russian icebreaker Minin ${ }^{1}$, trailed by the armed auxiliary yacht Iaroslavna, threw off its moorings and slipped out of the port of Archangel, breaking its way northwards through an arm of the frozen North Dvina estuary as it steamed for the White Sea. Aboard were General E.K. Miller, ${ }^{2}$

\footnotetext{
1 Koz'ma Minin (6,000 hp, 4,000 tons displacement, $75.6 \mathrm{~m}$ x 17.4m x $5.79 \mathrm{~m}, 14.5 \mathrm{knots})$ was built in England for the Russian Department of Commerce and Industries, by Swan, Hunter. Launched 1916, the icebreaker reached Archangel in February 1917. During the winter of 1918-1919, it worked in the White Sea, based in Archangel.

2 General Evgeii Karlovich Miller was born in 1867. In the First World War he rose through the officer ranks, earning a reputation as a capable strategist and able officer at high command levels. He fled Russia after the Revolution of 1917 because of a sentence of death delivered against him in absentia by a revolutionary military court. Asked to return to Northern Russia by Allied representatives in 1919, he was named by Admiral Kolchak as Supreme Head of the Government of Northern Russia. When British Prime Minister David Lloyd George terminated all military supplies
} 


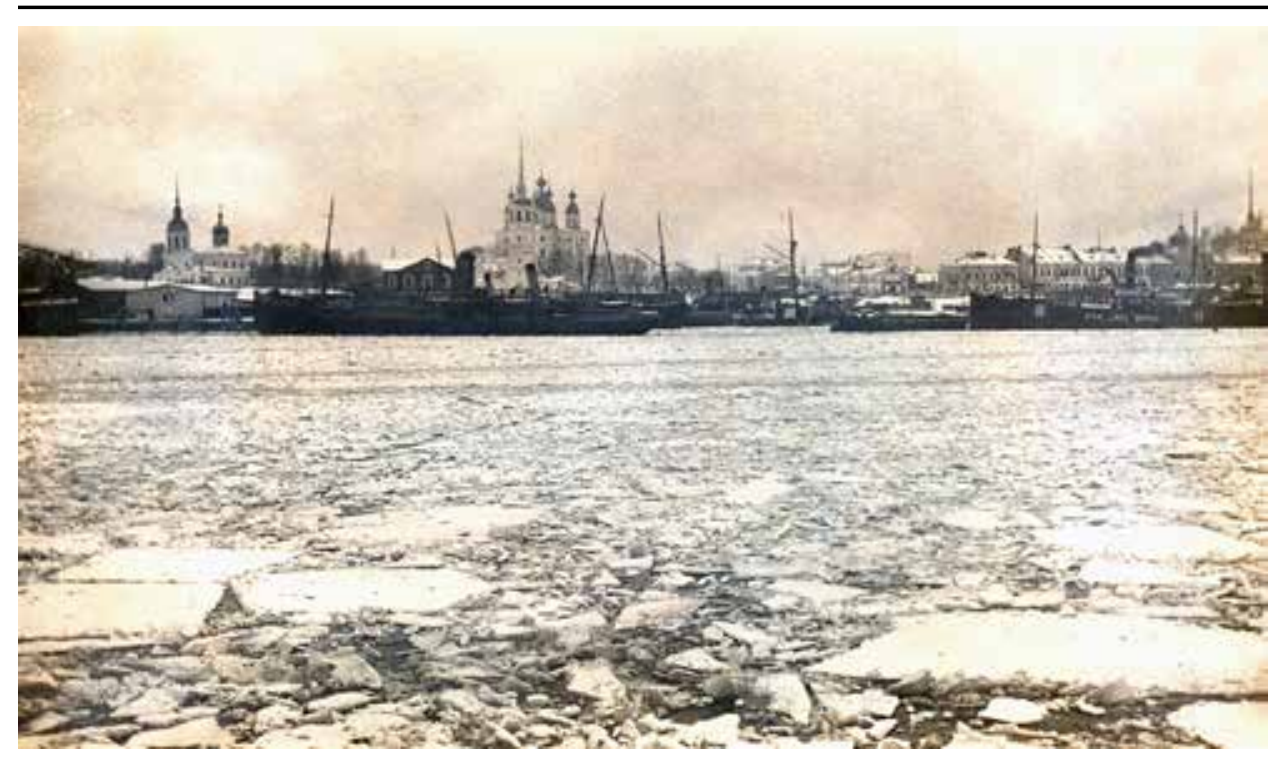

"Approach to Archangel from the Dvina River", from Library and Archives Canada, Dorothy Cotton Fonds, Volume 1, File "With the Anglo-Russian Hospital November 2, 1915 to July 1st 1916", 7

head of the White government of the Northern Region of Russia, his senior officers and their families, and those White officers, officials and civilians who had been fortunate enough to find a place on the two ships. The civil war in Russia's north was precipitously drawing to a close; pell-mell, General Miller and his people were fleeing the victorious VIth Red Army, then on the very outskirts of Archangel.

Minin intended to rendezvous with two more icebreakers, Kanada and Susanin, ${ }^{3}$ both berthed in Ekonomiia, the fore-port of Archangel some thirty miles downstream. Then, in convoy, the flotilla intended to continue on into the White Sea in search of safe haven. However, "men plan, but God decides," goes an old Russian proverb; and God, it seems, had other plans. In the end, only Minin managed to make the White Sea and, after a drama-laden voyage, find ultimate refuge in England. Along the way Minin and Kanada, which fell into Red hands and set out in pursuit of Minin, fought an artillery duel in the White Seat - the first, and probably only, instance of two armed icebreakers engaged in a sea battle. The

to forces fighting the Red armies in Russia in 1919, the days of that government were numbered. After his escape on Minin in early 1920, Miller fled to Europe, and settled in France. He became head of the Russian All-Military Union. He was kidnapped from Paris by Soviet agents in 1937, and executed in Moscow in 1939. (FB.ru>article/408387/general-miller-biografiya; and rusidea.org $>25051109$ )

3 Kanada (6,500 hp, 4,900 tons displacement, 250' x $47-1 / 2$ ' x $17-3 / 4^{\prime}, 17$ knots) had been built in England for the Canadian Department of Marine by Vickers, at Barrow-in-Furness, in 1909. It was made to a unique "knife-cutter" design. It had transported her namesake, Governor General Earl Grey, on his triumphant tour to Hudson's Bay in 1912. Sold to Russia in the late summer of 1914, it reached Archangel in October 1914 and immediately began icebreaking operations. Susanin, the ex-Canadian government icebreaker Minto $(2,900 \mathrm{hp}, 2,070$ tons displacement, $68.6 \mathrm{~m}$ x 9.9m x 4.62 m, 15 1 $\frac{1}{2}$ knots) had been built in 1899 by Gourlay Bros \& Co of Dundee, Scotland. The Canadian Department of Marine had sold the ship to Russia in 1915; it reached Archangel in January 1916. 
story of this flight, fight and ultimate escape follows.

\section{Collapse of the Northern Government}

When the Allies recognized that Intervention in Russia was spent they began evacuating Archangel in August 1919. The British urged General E.K. Miller, then head of the Northern Government, to evacuate his White Russian units as well, to withdraw at least to Murmansk, ${ }^{4}$ a place much more defensible than Archangel. Additionally, combining the two White forces (of Archangel and Murmansk) had obvious strategic and tactical value. Finally, should need arise, subsequent evacuation from Murmansk would be far easier; the port was largely free of ice in winter, far more distant from massed Soviet armies in the Archangel region, and, given the Kola Peninsula's much more difficult geography, that much more defensible by both land and sea.

General Miller refused evacuation. ${ }^{5}$ In retrospect, with this "most fateful decision to remain in Archangel after the evacuation of the Allies,", General Miller miscalculated gravely. He, with his limited forces, simply "could not present any truly significant and extended opposition" to the Bolsheviks. ${ }^{7}$ Relieved in late1919 of the multi-front threat to their grab for power (eastern, southern and western fronts secured), the Bolsheviks moved up thousands of troops and many heavy guns to the northern front. Their soldiers, by now, were battle-hardened, their officers experienced, their subterranean political organization throughout the North all-encompassing, and momentum was on their side.

The White forces, on the other hand, were in a far less enviable state. They could not but feel their isolation and a sense of abandonment after the departure of the Allies, who had always promised that they would be there with the White forces for the long haul. While the large complement of former Tsarist officers, as

\footnotetext{
4 The Allies also advised that all civilians connected with the White forces, as well as others who had anything to fear from Bolshevik retribution, should be evacuated. A number of civilians, somewhere in the order of 6,500, did choose evacuation, and were removed by the British for relocation to either the south of Russia or to the Baltic states newly-forming.

5 While 1919 tallied up as a disaster in the field for anti-Bolshevik White forces, General Miller believed that staying on at Archangel had both strategic and moral value. White Armies in the Archangel area posed a far more direct strategic and tactical threat to Bolshevik rule from Petrograd than would a force stationed on the far distant northern periphery of Russia. Moreover, in the fall of 1919, General Denikin's forces in the south had not yet been quite crushed. General Miller believed that the Whites in the south would yet rally there, and move to overthrow Bolshevik rule in Russia; hence it was imperative to hold Archangel and thus threaten the Bolsheviks with a two-front war. Finally, and perhaps most importantly, General Miller held to the position that evacuation of Archangel would give the Bolsheviks a great moral victory; in his opinion, victory in the Red-White struggle would be conditioned as much by morale and commitment as by the exercise of arms. Thus his resolve to hold on to Archangel, whatever the cost

6 "Manuscript. Red Sun at Dawn. Chapters VII-XVII," 195, Library and Archives Canada, Louise de Kirilline Lawrence fonds, MG $31 \mathrm{~J} 18$, Volume 3.

7 V.V. Klaving, Belaia Gvardiia [The White Guard], (St. Petersburg: Izdatel'stvo Ol'ga [Olga Publishers], 1999), 134.
} 
well as some of the ranks, were committed to the anti-Bolshevik struggle, such was not the case for very much of the rank-and-file. Many of them were conscripts (often impressed at that), local peasants who wore a uniform largely for the food and shelter which it secured them in the miserly and spartan Russian north which, in the best of crop years, could barely sustain its population. Their battle record throughout 1918 was far from stellar, with White units often refusing to fight, or simply going over to the other side. They wanted nothing more than an end to war and a chance to return to their villages.

However, General Miller might have been emboldened to stay on because of White successes in the field in the fall of 1919. His armies of more than 54,000 men had struck out into the hinterland of Archangel and driven Red units before them. He may have believed that a little bit more might secure the North for the Whites, blithely unaware that his blessed moment of victory had been possible only because the Bolsheviks treated the North as a secondary matter, to be addressed later. Perhaps he hoped to buy time for a possible White strike from Crimea under General Wrangel. ${ }^{8}$ Staying on was a gamble on his part - and thousands of White officers and families payed dearly for his unlucky roll of the dice.

As divisions of the VIth Red Army went into action in late 1919 and in January 1920 the White ranks, indifferent in their commitment and affected by Bolshevik propaganda, reeled before massed Bolshevik attacks, always preceded by heavy artillery barrages. White forces suffered a series of "crushing defeats." Miller's units fled, melted away or crossed over to the enemy side. The collapse cascaded in from the front, never more than 150 miles distant from Archangel at the best of times; only inclement weather, communications difficulties in unforgiving terrain and the delay required by Bolshevik quartermasters to re-supply their forces held up the Soviet advance during January and early February of 1920. With defeat and capture imminent no recourse remained for General Miller's government but flight; and in the frozen heart of Russia's Arctic winter, there was only one way out - on icebreakers.

\section{Flight of the Northern Government}

Only one icebreaker stood in the port of Archangel at the time of the White collapse, wrote a contemporary, S. Ts. Dobrovol'skii ${ }^{10}$ - "the story of its accidental appearance in our decisive hour in Archangel is not without interest

\footnotetext{
Gibel' Svernoi Armii, topwar.ru>167491-gibel'-severnoi-armii-millera-html.

Klaving, Belaia, 295.

10 S. Ts. Dobrovolskii, born 1891, was of hereditary gentry in St. Petersburg province. A jurist, he rose to the rank of prokurator (provost) of the XIth Imperial Russian Army. He left service following the Bolshevik seizure of power in 1917 and fled to Finland in 1918. He returned to Archangel in the spring of 1919 and became Field Prokurator (Provost) of the Northern Region / Front. He fled from Archangel on Minin. He settled in Finland, published much and was active in the Russian Military Officers Union. The Soviet government pressured Finland for his return after the Second World War, which, sadly, was arranged. He was executed in Moscow in 1946. (ru.wikipedia.org>Dobrovol'skii, Severin_Tsesarevich).
} 


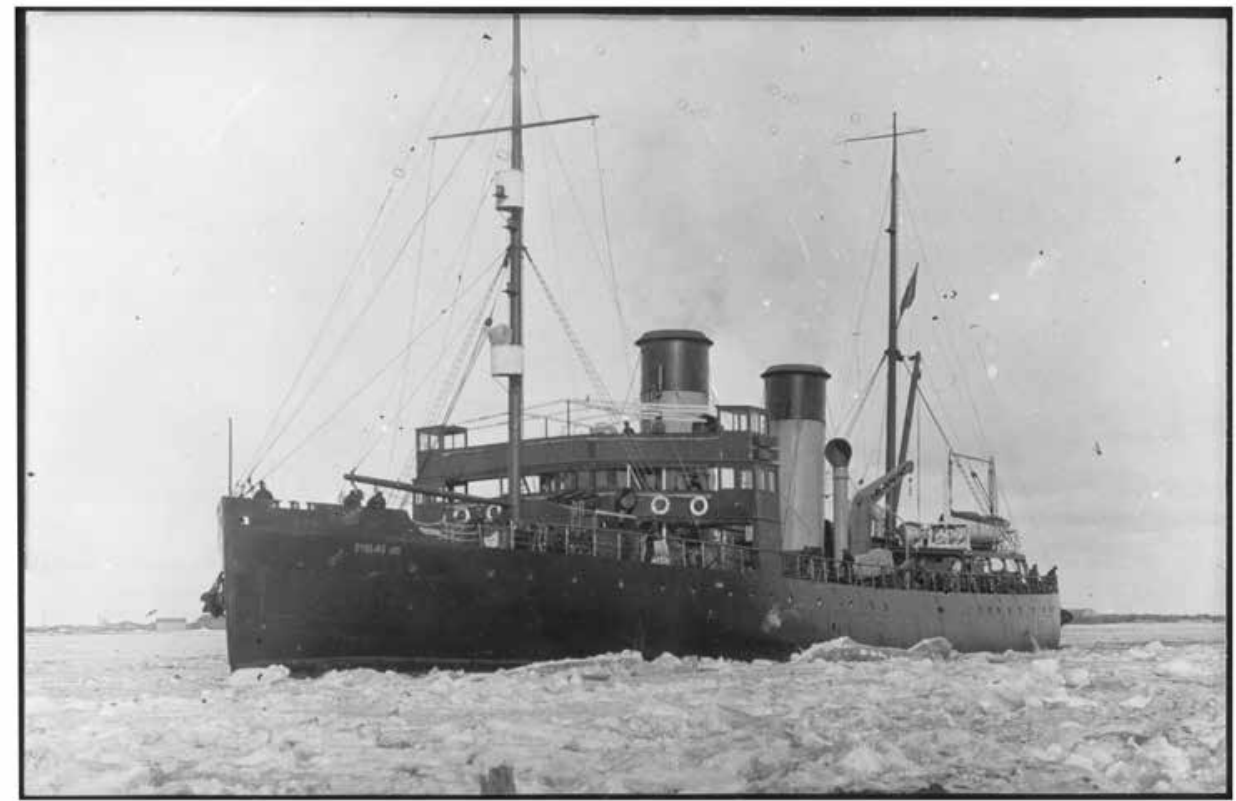

Ice-Breaker Koz'ma Minin (Photo courtesy of V. Andrienko, from collection of D. Vasiliev, both of St.Petersburg, Russia)

and I will ... share it with you," he wrote later in his memoirs. ${ }^{11}$ General Miller's military command, as late as mid-February and with Bolsheviks units making great advances, seemed, in Dobrovol'skii's estimation, strangely unaware of the precariousness of its position. On 15 February 1920, just three days before the panicked evacuation from Archangel, the command had sent four icebreakers Kanada, Minin, Rusanov and Sibiriakov ${ }^{12}$ - into the White Sea, to transport officers and workers to Murmansk and to return with provisions to Archangel. Given the parlousness of the White positions in the North, it remains moot at best as to why General Miller chose to send them out at this time. ${ }^{13}$ As B.F. Sokolov, ${ }^{14}$ another

11 S.Ts. Dobrovol'skii, "Bor'ba za vozrozhdenie Rossii v Severnoi Oblasti" ["The Struggle for the Re-birth of Russia in the Northern Region"], in V.I. Goldin, ed., Belyi Sever 1918-1919. Memuary i dokumenty [The White North 1918-1920. Memoirs and Documents], Issue I, (Arkhangelsk: Pravda Severa [Truth of the North Publishers], 1993), 183.

12 Rusanov (ex-Bonaventure) and Siriakov (ex-Bellaventure) were former sealing steamers acquired by the Russian Department of Trade and Commerce from Newfoundland interests in late 1915. General Miller also sent out at this time Taimyr (a Russian-built ice-capable vessel, which, along with Vaigach, had done the first east-west transit of the North-East Passage in 1912-1913), as well as the transport Poliarnyi.

13 In General Miller's defence, it might be pointed out that the front collapsed on 18 February, and while there had been plans for retreat of White forces to Murmansk, that was not the case for Archangel proper (O. Pauller, "Evakuatsiia Severnoi Oblasti" [Evacuation of the Northern Region], samlib.ru>Zhurnal Samizdat>oleg...pauller).

14 B.F. Sokolov was a leading figure of the White government of Archangel. A physician, publicist, social activist and a member of the Socialist Revolutionary Party, he was an instructor at Petrograd 
contemporary who participated in the evacuation, wrote later, "this departure [of icebreakers] was incomprehensible to me, as it was to everyone else. This happened at a time when the [imminent] fall of the Northern Region was evident to all, when everyone was speaking only of evacuation from Archangel." 15

Of the icebreaker fleet at General Miller's disposition, only the weaker Susanin remained behind, in Ekonomiia, far downstream from Archangel. However, not wholly unaware of the tenuousness of his situation, when despatching the other icebreakers to Murmansk, General Miller had impressed upon their masters the imperative to keep in constant radio contact in the event that their immediate return might be required. The most loyal of the captains of the icebreakers, identified by Dobrovol'skii only as Captain "Z," "16 master of Minin, had kept an eye out on his outward voyage for the quickest possible route back through the ice should an SOS come from Archangel. And when that signal came on 16 February, Minin alone of all the icebreakers made the port of Archangel and, "in this manner," as Dobrovol'skii put it, "saved our lives." As Minin docked on 17 February loyal officers secured all machine and boiler stations and assumed strict control over the unreliable crew. Kanada also returned, though a day later on 18 February; but it docked at the port of Ekonomia (where Susanin was moored), some thirty miles down river, to take on coal. On that same day the two vessels received instructions from General Miller to prepare to evacuate sick and wounded White personnel, as well as refugees, who were on their way by train to Ekonomiia to board Susanin and Kanada. ${ }^{17}$ On 18 February as well General Miller secretly gave instructions to select individuals to board Minin that very evening, with their families, while publicly advertising that general withdrawal would commence at 2:00 p.m. the following day. At 11:00 a.m. the following morning, a full three hours before general boarding, the icebreaker, with the armed auxiliary yacht Iaroslavna in tow, ${ }^{18}$ cast

University during the Great War. He was a close associate of A.F. Kerensky, who had headed Russia's Provisional Government, and was elected to the Constituent Assembly, which the Bolsheviks closed down after their seizure of power. He came to Archangel from abroad in 1919, and became a member of the last White government in February, on the very eve of its fall. He evacuated on Minin. When Minin reached three other icebreakers trapped in the ice at the throat of the White Sea, General Miller, whose political views differed sharply from Sokolov's, cruelly ordered him left behind on Rusanov, one of the breakers fast in ice. Arrested by the Bolsheviks, he was later released and went abroad, writing prolifically about the Revolution, Civil War and life in the Emigration. He died in 1979 in New York (ru.wikipedia.org $>$ Sokolov, Boris Fedorovich).

15 B.F. Sokolov, "Padenie Sevenoi Oblasti" ["The Fall of the Northern Region"], in V.I. Goldin, ed., Belyi Sever 1918 - 1920 gg. Memuary i dokumenty [The White North 1918-1920. Memoirs and Documents], Issue II, (Arkhangelsk: Pravda Severa [Truth of the North Publishers], 1993), 389.

16 I have come across a source which identifies the commander of Minin as Rear Admiral B.A. Vil'kitskii, a famed arctic explorer, who successfully deceived a disloyal crew to get his vessel back to Archangel (Pauller, "Evakuatsiia").

17 Dobrovolskii, Bor'ba za vozrozhdenie, 183-184.

18 The Iaroslavna was the flagship of the Russian naval fleet in the north. At that moment she was undergoing repair, with her engines disassembled, While without power, Iaroslavna provided space for evacuees, carrying aboard it military and civilian administrators, some of the wounded, families of officers, veterans still loyal to General Miller, as well as a unit of Danish volunteers (Pauller, 
free, easily breaking the even river ice. The White flight from imminently Red Archangel had begun. ${ }^{19}$ Dobrovol'skii noted that some desultory and harmless shots were fired at Minin as it drew away from shore. ${ }^{20}$

Dobrovol'skii, a senior officer, was not particularly critical of General Miller, Admiral Ivanov ${ }^{21}$ and White headquarters staff regarding the panicked White flight from Archangel. Not so Colonel N.P. Zelenov, ${ }^{22}$ also a contemporary who had served in the field as chief of artillery of the Dvina front; in his memoirs he drew a very different picture of Minin's putting out. "On 19 February 1920 the icebreaker... Minin ... left Archangel amidst shrieks of incomprehension of those left ashore. Curses came from the mouths of the local Bolsheviks ... and also from the Whites - for whom there had been no room on the ship."23 Zelenov's version is by far the more believable, confirmed by another observer who wrote, regarding Minin's departure: "a large crowd gathered opposite ... Miller's ships. There were many [White] military men here. A firefight commenced between Minin and the crowd [left behind] on shore. The ships [Minin and Iaroslavna] fired their guns, while the crowd returned fire with machine guns. There were casualties on both sides. The icebreaker Minin left Archangel under fire."24 Passing the cargo docks, an observer wrote, "we [saw] individual black spots, running to us across the ice those [were] officers who caught up with the icebreaker at Solombala," 25 and were pulled aboard.

\footnotetext{
"Evakuatsiia").

19 A source indicates that there were 600 military and family aboard Minin and another 200 aboard the Iaroslavna. Miller himself was aboard the latter, commanded by Admiral Vil'kitskii (https:// rusidea.org/25051109), while the former, with Admiral Ivanov aboard, was commanded by Captain G.E. Chaplin (Pauller, "Evakuatssia").

20 Dobrovolskii, Bor'ba za vozrozhdenie, 184. Another source suggests that several people aboard Minin were wounded ("Sever i Zapoliare v borbe s bol'shevizmon," ["The North and the Arctic Region in the Struggle with Bolshevism"] k2x2info>istorija/tainy-belogo dvizheniia)

21 Rear Admiral Leonid Leont'evich Ivanov was born in 1875. After command positions in the Imperial Russian Navy, including as flag officer of a division of destroyers in the Black and then Baltic Seas, in 1918-1920 he commanded the northern fleet based in Archangel, formally the Fleet of the Northern Frozen Ocean. After his escape from Archangel he settled in Italy. He died in 1940 in Rome. (https://rusidea.org/25051109).

22 N.P. Zelenov was born in 1884 in Samara. He served as an artillery officer in the First World War on three fronts. From August 1918 to February 1919 he served in the White forces of North Russia and was promoted to colonel in 1919. He managed to make his way onto Minin in the very last moments before its departure. He settled in Hermola, Finland, and much later moved to France, where he was a member of the Russian Military Republican League. Death date unknown. (www. ria1914.info-Zelenov, N.P.)

${ }_{23}$ N.P. Zelenov, "Tragediia Severnoi Oblasti" ["The Tragedy of the Northern Region"], in V.E. Goldin, ed., Belyi Sever 1918-1920 gg. Memuary i dokumenty [The White North 1918-1920. Memoirs and Documents], Issue II, (Arkhangelsk: Pravda Severa [Truth of the North Publishers]), 1993, 203. ${ }_{24}$ M.B. Chernenko, "Delo voennogo moriakia Nikolaeva" ["The Case of the Naval Sailor Nikolaev"], Letopis' Severa [Chronicle of the North], 4 (1964), 218.

25 "Kak 'Kozma Minin' na 'kanadtsev' opolchilsia: ili duel' ledokolov," [“How Koz'ma Minin Rose Up Against 'the Canadians': or, The Duel of the Icebreakers"], (141840.livejournal.com>52432. html.)
} 
The evacuation was, in Zelenov's eyes, a criminal betrayal. In fact, throughout the whole winter the military command in Archangel proper had had little to fear for themselves and their families, even as White fortunes had steadily declined; "with the presence in the water of powerful miracle-icebreakers," their escape was always assured. But they had manifested little concern for the thousands of White officers, loyal and still in the field; for their families scattered throughout outlying villages; and for those at the front under constant threat of slaughter at the hands of either Red forces or their own unwilling conscripts. The collapse of the front was already evident by 13 February, in Zelenov's opinion, and with the icebreakers then still at hand (the Susanin and now the returned Kanada at Ekonomiia, and Minin and the port icebreakers No. 6 and No. 9) there had been time enough to organize a near-complete evacuation of all desiring to leave. ${ }^{26}$ The General Staff had had neither the courage to admit defeat at the proper time, nor the administrative skill to prepare an organized withdrawal. ${ }^{27}$ Again, Zelenov felt, the loyal soldier had been betrayed in the field by his own general staff, a sentiment endemic to Russian soldiers throughout the First World War, the Revolution and the period of the Intervention. Once again, thousands of desperate officers, soldiers and families had been abandoned to the unkind mercies of their mortal foe by a commander-inchief who had ceaselessly assured them that "he would never desert them for any reason whatsoever," 28 [and that] "if necessary to retreat, he would retreat together with them, and lead them out." 29

By 2:30 in the afternoon of 19 February Minin reached Ekonomia, intending to take on coal and join forces with Kanada and Susanin. However, Kanada and Susanin surprised everyone aboard by running up red flags; at the same time some officers, fleeing from these icebreakers, dashed across the ice to Minin and were hauled aboard. They reported that lax security on the part of the port commander had allowed bands of Bolshevik sailors and Red units on the outskirts of Archangel to seize all port facilities, as well as Kanada and Susanin. Though short on coal,

\footnotetext{
26 In fact,Zelenov was unaware of several more ice capable ships - Rusanov, Sibiriakov, Taimyr and the transport Poliarnyi - which were also available. With this ice breaking capacity, and a number of other smaller transports available, General Miller could easily have evacuated 10,000 persons at the least, i.e. probably all who would have wanted, or needed, to leave.

27 Zelenov, "Tragediia," 227.

28 According to Admiral Vil'kitskii General Miller, right to the very last, refused evacuation and intended to stay with his troops. Only when Colonel L.V. Kostandi assured him that White forces were breaking out towards Murmansk did he board Minin - a half-hour later, the icebreaker drew away (Pauller, "Evakuatsiia").

29 Chernenko, "Delo Voennogo," 218. Zelenovs's interpretation was broadly shared. For example, Louise de Kirilline Lawrence, a Swede married to a White Russian officer, was in the area; she and her husband were among the thousands abandoned, and her husband later shot. In her unpublished memoirs, she writes about the flight as follows: "why ... that awful waste of two weeks' time after the collapse of the front? Why let three icebreakers leave the falling citadel almost empty - three icebreakers that could have saved so many? Why had they abandoned ship in the only safe life-boat and left all of us to be drawn into the sucking vortex of the wreck?" "Manuscript, ms note following p 193, Library and Archives Canada, MG 21 J18, Vol 3.
} 
and with a thousand desperate souls crammed aboard the icebreaker and the yacht, Minin had no option but to head for the White Sea. The ranking naval officer on Minin, Admiral Ivanov, in a futile and formalistic exercise, signalled Kanada to lower its red flag and to follow him, threatening to open fire in the event of noncompliance. Kanada did not stir; as it drew away Minin fired thirty rounds in the direction of Kanada, a more than pointless action, since, by that time, both the ship and the port had faded from sight.

By nightfall Minin met up with massive, rafted ice fields in the Dvina's mouth and, in the dark and the ice, the icebreaker could keep Iaroslavna in tow no longer. After the transfer of all refugees, goods, coal and provisions to Minin during the night, the yacht was cast loose. ${ }^{30}$ Minin, with a normal complement of 112, now had 1,100 persons aboard as it made for the White Sea. ${ }^{31}$

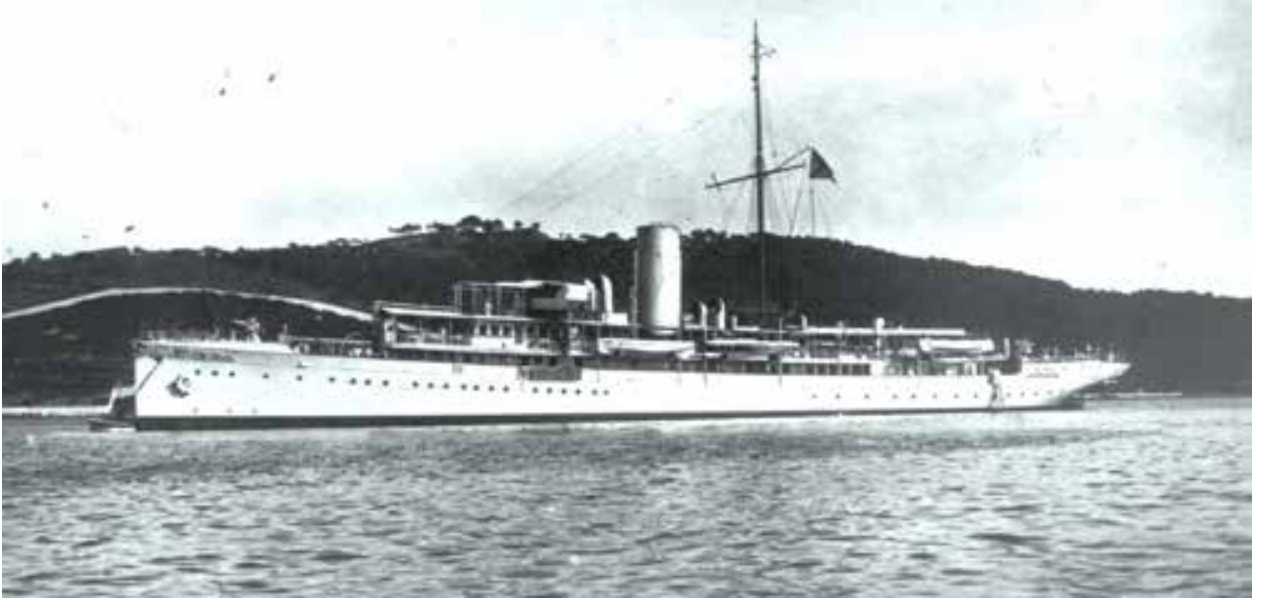

laroslavna with Gun, Flying the Russian Naval Ensign (St. Andrew's Cross), 1919 (Yandex.ru)

In the early morning of 20 February Minin intercepted wireless signals between Archangel, now fully in Bolshevik hands, and the ice capable ships Rusanov, Sibiriakov and Taimyr which, as noted above, General Miller had earlier unwisely despatched to Murmansk (on 15 February). Archangel advised those ships that Minin was headed for the White Sea and, should it call, the three vessels were neither to respond, nor to show any night lights. Later in the day, as it worked through the ice, Minin did spot the three vessels. Smaller, with less powerful engines than true icebreakers, they were stuck fast in pressure ridges in the throat of the White Sea.

Minin, by then very low on coal, broke towards them. Admiral Ivanov radioed

30 Iaroslavna was later rescued by Red forces and inducted into the Soviet Northern Flotilla as a shore patrol vessel (Gibel'Severnoi Armii).

31 Dobrovol'skii, “Bor’ba za vozrozhdenie," 189-190; Zelenov, “Tragediia,” 229. 
the ships to show their lights, as it was growing dark; Minin's size and much heavier armament, as well as the desire of some of the senior personnel aboard the three immobilized vessels to escape Red Archangel, assured compliance with the order. Towards 8:00 o'clock in the evening, in winter darkness, Minin drew near, its machine guns at the ready. The guns proved unnecessary. The White command aboard Minin decided to strip enough necessary coal and provisions from the small ice capable ships to assure its own escape, and to take on officers and other personnel being transported to Murmansk, whoever wished to escape the Bolsheviks. Minin drew up alongside Sibiriakov and started to take on coal, while additional refugees came aboard. ${ }^{32}$ A refugee aboard Minin, observing this scene, described it later thus; "this picture of lighted icebreakers with quicklymoving and armed people aboard them in the midst of a deathly ice stamped into my memory an unforgettable impression, and it could have served as a wondrous subject for a cinematographic film." 33

\section{Icebreakers at War}

On the morning of 21 February, with Minin still coaling from Sibiriakov, towards 11:00 o'clock in the morning, "far to the south," as Zelenov writes, "[there appeared] some smoke, [and] in a short time the silhouette of the icebreaker Kanada crystallized out. Somewhat later still came its shots." 34 Thus, near Sosnovets Beacon in the throat of the White Sea, only several kilometres south of the Arctic Circle, there occurred "an extraordinary, in all likelihood the first, armed battle between two icebreakers. Falling shells tore the thick ice, and frightened off herds of seals." 35 Zelenov's account of what ensued is rather cryptic, what one would expect from a field officer. Kanada drew nearer, its shooting became more accurate. Minin stopped coaling, drew away from Sibiriakov as quickly as possible, and answered with its cannon. The battle was short - Kanada fled, Minin was the victor. ${ }^{36}$

Dobrovol'skii's recollection, which follows, provides far richer detail about this extraordinary moment in maritime history. At the same time that Kanada appeared on the horizon Minin intercepted its wireless to Archangel - "see on the horizon four ships, do not answer call to surrender. Opening fire. Commissars Dubrovskii, Bubnovskii and Nikolaev." Kanada opened fire at a range of five versts (slightly more than five kilometres). Standing right up to Sibiriakov from which it was still coaling Minin could not immediately respond. Coaling broke off instantly and Minin began to draw away from Sibiriakov while shells from Kanada started to come in "very accurately and close to Minin. Kanada's first shots were very much on the mark. Short, short, then overshot; as artillerymen say, we'd been

\footnotetext{
32 Dobrovol'skii, "Bor'ba za vozrozhdenie,"190; Zelenov, “Tragediia,” 229.

33 Dobrovol'skii, “Bor'ba za vozrozhdenie,"190.

34 Zelenov, "Tragediia," 230.

35 Chernenko, "Delo voennogo moriakia," 218, 221.

36 Zelenov, "Tragediia," 230.
} 
'forked.' Only the squeezing of the tines remained." ${ }^{37}$

However, Minin managed to get around in time to answer with her $102 \mathrm{~mm}$ stern gun, "a big surprise for the enemy," since they had believed Minin carried only small ordinance. (The gun had actually been removed from the Iaroslavna before she had been cast loose the preceding night and installed on Minin). Minin's shooting proved effective; soon Kanada began a slow turn-about and then swiftly bore back southwards. "Thus ended our naval engagement," writes Dobrovol'skii; "as I learned much later, when abroad, the reason for this successful conclusion was [the fact] that one of our shells struck Kanada." ${ }^{38}$

Sokolov, watching events from on board Rusanov, to which he had been transferred by Miller because of his political orientation, gives the following description of this extraordinary engagement, interesting both for its different vantage and for its evocative literary quality.

Towards 10 o'clock in the morning on 21 February the transfer of coal and passengers from the ships onto Minin was coming to an end. The loading had progressed rapidly, not without many incidents.

Unexpectedly a ship appeared on the horizon. This was the icebreaker Kanada, armed by the people [of Archangel] for pursuit [on the heels of] the hectic flight of General Miller. Kanada carried some tens of sailors, three artillery officers and the commissar Nikolaev, then in charge of the [Red] White Sea Fleet.

Kanada radioed Minin to surrender. Minin did not respond. Then the shooting began.

What a scene of unparalleled beauty.

The White Sea - from shore to shore surfaced over by thick rafts of ice. These sheets climbed out one onto another, rearing up precisely as if they were polar bears. A blindingly bright polar sun, giving off no heat, fracturing into a thousand points of brilliance in droplets of frozen moisture.

Three small ships, fully covered in ice right up to their gunwales, seeming sacrifices offered up to the Nature [god] of the North, ever freezing and never-sated.

In the centre of this ice field two large icebreakers. Slowly, as if they were beetles or crabs, crawling backwards and forwards on the fiercely disobedient ice.

Every now and then, desultorily, shots sound, losing themselves in muffled echos across the white snowy plain. A shells falls to the ice, and scatters high and wide the shattered shards of ice.

For us on Rusanov ... the [potential] outcome of this battle was

37 Dobrovol'skii, "Bor'ba za vozrozhdenie,"190. Kanada actually had 180 revolutionary soldiers and sailors aboard (Chernenko, "Delo voennogo moriaka," 221).

38 Ibid., 191. 


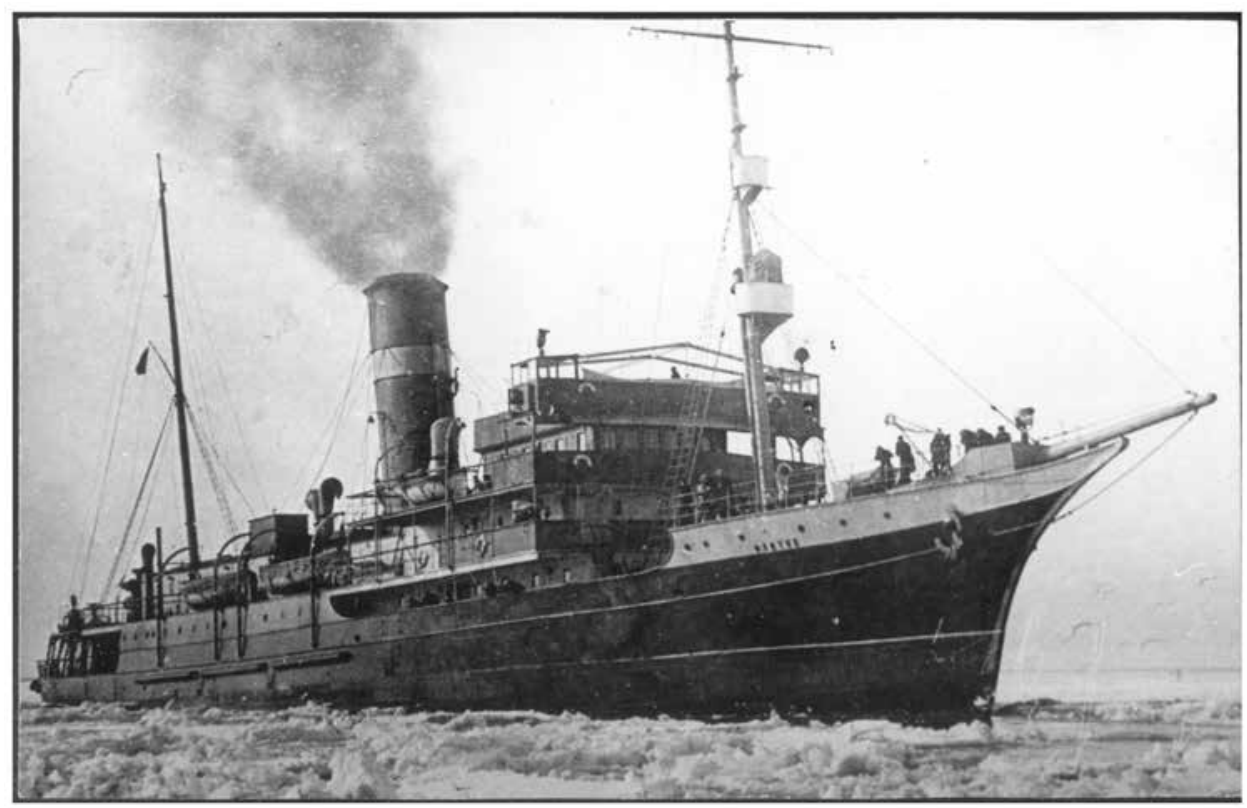

The Ice-Breaker Kanada (ex-Earl Grey), After its Re-naming as Litke -- Photo Courtesy of V. Andrienko from Collection of D. Vasiliev, both of St. Petersburg, Russia

particularly disturbing. It seemed that Kanada, [if she drove off] Minin, would take us captive and then would follow our merciless execution by the Bolsheviks. But then, unexpectedly, after it had fired several shots, Kanada went about and, after standing for a time in one spot, soon hid itself beyond the horizon. Shortly afterwards Minin, clearing for itself the required open water, began to move northwards.

We were left alone [in the ice].

The unexpected departure of Kanada, as it came out later, was caused by a crack which had developed in the icebreaker's [stem]. The poorly and unprofessionally installed canon had exacerbated damage received by the ship in an earlier mishap. ${ }^{39}$

Had Kanada had been hit by Minin, as Dobrovol'skii suggests? Had it been, as Sokolov writes, a crack opening up somewhere in Kanada which had forced her to break off the engagement? Or was it as I.A. Danilov, ${ }^{40}$ yet another contemporary who remained behind in Archangel, reports, simple cowardice on the part of the

39 Sokolov, "Padenie," 406-407.

40 I.A. Danilov was born in 1881 in St. Petersburg, the son of a highly-placed official, and later an infantry officer (captain in 1914, colonel in 1917). He reached Archangel in November 1918, held a number of commands and ended up as chief of White army forces on the Dvina Front, where he was promoted to major general. He was taken prisoner by the Bolsheviks. He served time in prison, then performed forced military service for Bolsheviks on the Southern and Polish Fronts. He retired from service March 1922, after which he fled to Finland and settled in Porvu. He died there in 1954. (ru. wikipedia.org>wikiDanilov,_Irodion_Andreevich). 
Bolsheviks aboard Kanada? Imprisoned by the Bolsheviks after their seizure of Archangel, Danilov heard the following from Colonel Kostandi ${ }^{41}$ about the Kanada-Minin battle while they were both incarcerated, as well as on how Kanada came to be seized by Bolshevik elements in Ekonomiia when the flight first set in motion.

Kostandi [when in Archangel prison] ... told me he had seen the captain of the icebreaker Kanada, who had returned from his unsuccessful pursuit of Minin. The truth of the matter was, as the captain of Kanada explained to him, neither he himself nor the crew of the icebreaker had intended to remain in Archangel because they were all paid by the British and even their families were then in England. At that very moment when Minin was heaving away in Archangel a group of soldiers and sailors burst onto Kanada ... and forced [the command] to hoist a red flag. The seizure notwithstanding, as Minin approached Ekonomiia the captain of Kanada wanted to come about, make for the channel and lead Minin out to sea, and thus to quit Archangel but, unfortunately, (and this, in all probability could not have been otherwise), Minin took this as a threatening gesture, and Iaroslavna, then being towed by Minin, opened fire on Kanada. The captain of Kanada ceased his efforts at flight, [Red] guards were placed at his side and the icebreaker Minin passed on by. After this there appeared aboard Kanada some self-styled commissars, who despatched to the ship all sorts of sailor and soldier trash, about two hundred in number, dragged on board two field artillery pieces [3" guns] and fixed them in some manner or other onto the deck, one of which had not functioned even ashore, and threw themselves into pursuit after Minin, forcing the captain, of course, to run the ship for them. As the captain of the ship explained, all this scum did not allow for the fact that Minin was armed and, when they drew near to it and signalled it to surrender, and in response received [fire], all lost their senses. After several shots the second artillery piece also ceased to fire, right when a shell from Minin exploded very closely to Kanada. Then all these villains, fearing for their skins, cleared the deck and stuffed themselves into the hold and cabins, threatening the captain, who was on

\footnotetext{
41 Colonel L.V. Kostandi, born in 1883, had served in the Galician campaign in 1914. In 1916 he was named chief of land defences of the Peter the Great Naval Fortress in Reval. Remaining in service after the Bolshevik seizure of power, he was named to HQ of the White Sea Military Region. He joined the Whites in August 1918 when the Allies intervened in North Russia. A capable organizer and successful field leader, he resolved to stay on after the flight of the White military and government officials. In fact, Miller formally transferred military command to Kostandi at the time of his departure. Kostandi hoped that, in remaining, he could lessen the excesses to which the inhabitants of Archangel might be subjected by marauding Reds until his formal surrender to Red officials. As some have observed, it was a "noble but suicidal" act. Imprisoned in 1920-1921, he was executed after the Kronstadt sailors' rising against the Bolsheviks in 1921. "He fulfilled his officer's duty to the very end." (Avtor i ego vremia [The Author and His Time].oddesitclub.org).
} 
deck, with rifles and revolvers from open portholes and screaming, "Turn back, turn back." The captain of the ship, of course, had to obey their command, and Kanada returned to Archangel. ${ }^{42}$

After Kanada stood away southwards, the battle done, Minin began working its way north. "As it was leaving, it ordered Rusanov, Sibiriakov and Taimyr: 'Follow us.' This command, given to vessels sealed in ice, was a joke." ${ }^{43}$

A Soviet commentator, M.B. Chernenko, working from notes compiled by M.V. Nikolaev, the Bolshevik naval commissar who organized Kanada's pursuit of Minin, suggests that there were two engagements. However, given that all memoir sources speak of only one engagement he is probably off the mark, ${ }^{44}$ all the more likely given that a detailed report on these events in the White Sea by Captain S. Butakov, master of Sibiriakov at that time, speak only of one battle. ${ }^{45}$

\section{Escape}

Minin and its refugees were not free of danger following the battle. In the chaotic flight from Archangel, General Miller had not even arranged for the disabling of that port's wireless station. On 20 February messages had sped to Murmansk that Archangel was in Red hands. This immediately precipitated a rising in Murmansk by Red sympathizers on 21 February; the following day the port came under

42 I.A. Danilov, "Vospominaniia o moei podnevol'noi sluzhbe u bol'shevikov" ["Memoirs Regarding My Involuntary Service For the Bolsheviks"], in V.I. Goldin, ed., Belyi Sever 19181929 gg. Memuary i dokumenty [The White North 1918-1920. Memoirs and Documents], Issue II, (Arkhangelsk: Pravda Severa [Truth of the North Publishers], 1993), 294-295.

43 Sokolov, "Padenie," 407. It is not all that certain that Sibiriakov and Rusanov could not have broken free of the ice that held them fast. Captain S. Butakov of Sibiriakov, in his report to Bolshevik naval authorities on these events in the White Sea, indicates that he resolved not to follow Minin, to feign inability to break through, that he moved to block Rusanov's attempt to follow, and subsequently replaced the captain on Rusanov. That they could have followed is demonstrated by the fact that both Sibiriakov and Rusanov did, several days later, break their way to Murmansk. S.I. Butakov, "Dokladnaia zapiska kapitana ledokol'nogo parakhoda A. Sibiriakov S.I. Butakova o begstve belogvardeitsev iz Apkhangel'ska" ["Final Report of the Captain of the Ice Breaker $A$. Sibiriakov, S.I. Butakov, on the Flight of the White Guardists From Archangel"], in A.E. Ioffe et al, eds., Voennye moriaki v borbe za vlast' sovetov na Severe (1917-1920) [Naval Sailors in the Struggle for the Victory of the Soviets in the North (1917-1920)], (Leningrad: Akademiia nauk [Academy of Sciences]), 1982, 342 .

44 On 21 February, writes Chernenko in his narrative, the first engagement made it "clear that Minin's artillery was more powerful," forcing Kanada to break off the engagement and make way southwards. Then, he continues, "the evening mist descended, and snow began to fall ... The icebreaker Kanada, showing no lights, was enveloped by darkness. [Also] benefiting from the darkness, dousing all lights, Minin strove to escape pursuit ... But breaking out of the ice of the White Sea throat is no simple matter. The morning found the White squadron [Minin and the three other vessels locked in the ice] almost in the same spot ... Again Kanada caught up with the fleeing interventionists ... Minin fired back ... Ten minutes later one of Kanada's guns went out of action. It became very clear that Minin's artillery was now far superior... Minin broke out into the open sea. Further pursuit was pointless." Chernenko, "Delo voennogo moriaka," 221.

45 Butakov, "Dokladnaia zapiska kapitana," 341-344. 


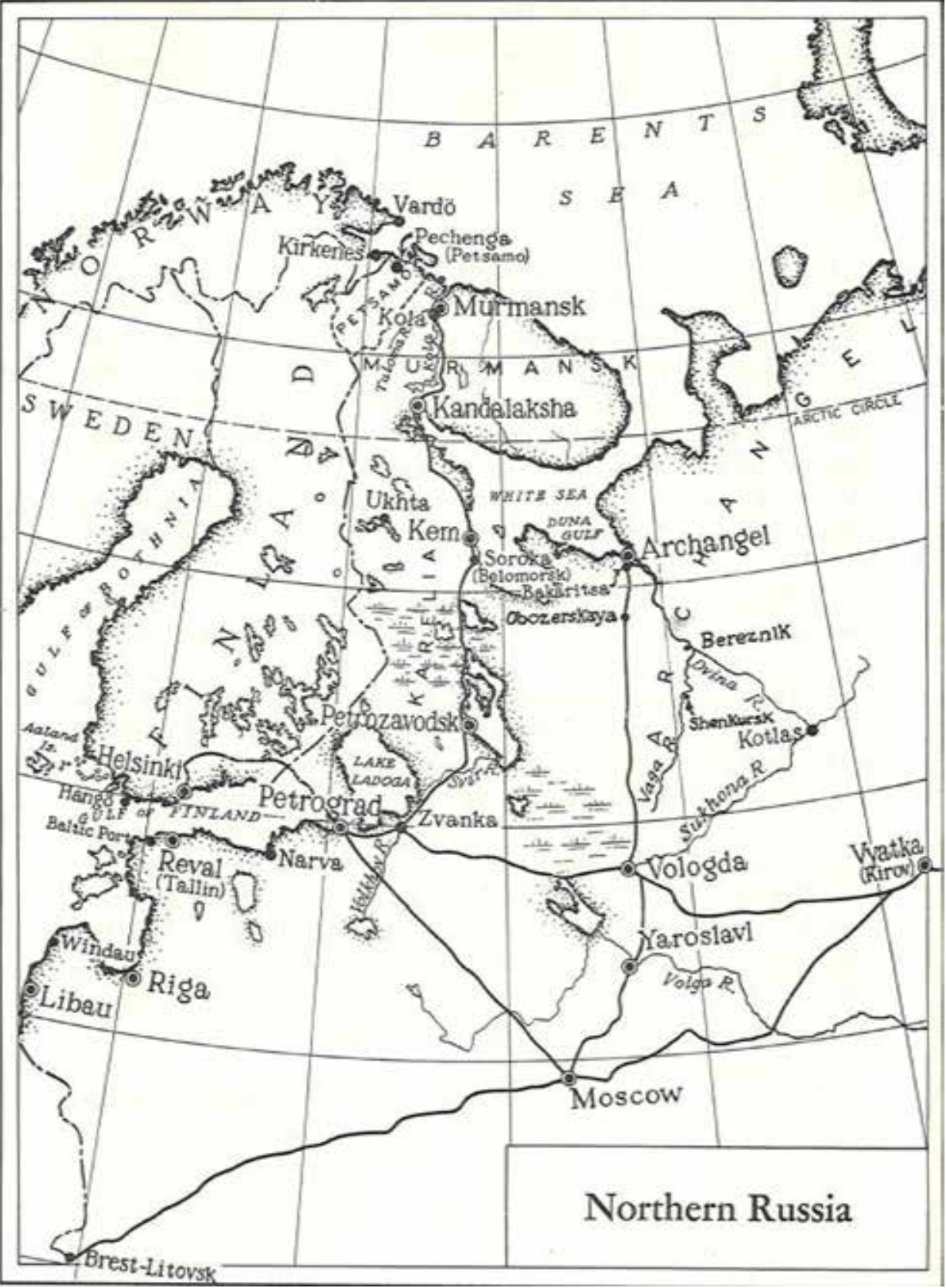

Richard H. Ullman, Anglo-Soviet Relations, 1917-1921. Intervention and The War, (Princeton University Press), Princeton (NJ), 1961, 110. 
Bolshevik control. In a telegram of 22 February, N. Kuzmin, a member of the Revolutionary Military Council of the VIth Army, which had entered Archangel on 21 February, telegraphed as follows to the Soviet of the Republic in Petrograd:

Murmansk radio announces that the overthrow is complete, that the [White] authorities have fled on the icebreaker Lomonosov. The probability is [that they are heading] for Pechenga or Norway. The whole western shore [of the White Sea] has been notified ... Kanada attacked Minin, but without success and, advising that Minin's guns were heavier, returned. I offered Miller [an opportunity] to surrender, guaranteeing him his life. I am telegraphing Murmansk to despatch armed vessels to seize Minin. ${ }^{46}$

Minin had in fact intercepted wireless on 21 February that Murmansk was in rebellion and thus fully intended to avoid it. To its great good fortune, "God's mercy" as a contemporary put it, on 22 February the prevailing winds changed, the ice jams parted and the ship broke through the torturous barrier of ice ridges in the throat of the White Sea into open water. To avoid its pursuers, showing no light whatsoever, it went well wide of the shore, rounding the Kola Peninsula almost several hundred kilometres to the north near the southern limit of the polar ice fields. On 25 February Minin put into the nearest navigable fjiord in Norway and there, wholly unexpectedly, met up with Lomonosov ${ }^{47}$ and its passengers, the pitiful few who had escaped from Murmansk during the Bolshevik uprising which secured Red power in that port - a handful of Russians, some Belgian volunteers and two British flying officers.

To ease overcrowding part of Minin's passengers boarded Lomonosov and the two vessels made for the sea. On 25 February, out of necessity setting aside their fears regarding possible internment and forced return to Soviet Russia, the refugees put in to Hammerfest, Norway, where they were astounded by an extraordinarily warm and humane reception by the locals. On 25 February they docked at Tromso, where aid and assistance was equally solicitous and generous. ${ }^{48}$ The refugees remained in Norway until June, when they were admitted into the United Kingdom. Minin later made for Trondheim, and then London, where its near-epic flight ended, and the vessel passed over to the control of the Russian Committee for Wrangel.

\section{Conclusion}

The fall of the White government of the Northern Region was a victory of great

\footnotetext{
46 I. Mints, Interventsiia na Severe $v$ dokumentakh [Intervention in the North in Documents], (Moscow: Partizdat [Party Publishers]), 1933, 93-94.

47 Lomonosov was the former Eclipse, a small, Dundee-built whaler of 430 tons, with a wooden hull sheathed in metal, driven by a 69 hp engine. Built in 1867, she was bought from Scottish interests in 1914 when Russia began to acquire ice capable ships for work at Archangel and, later, at Murmansk.

48 Dobrovol'skii, “Bor'ba za vozrozhdenie," 191-192.
} 
significance for the Soviet government, freeing Petrograd from the danger of a proximate front. That General Miller and his senior officers escaped rankled the Bolsheviks; but they made do with other trophies of war - the thousands of White officers, soldiers and their families abandoned by General Miller.

General Miller never quite lived down the ignominy of his abandonment of his army in the field. ${ }^{49}$ In the Russian diaspora throughout Europe his "evacuation" of Archangel was always compared to Baron Wrangel's withdrawal from Crimea in 1920, and always to the General's great disadvantage. ${ }^{50}$ Still, this did not stop Miller from later becoming head of the Russian Military Union, the largest Russian emigre military organization in Europe. Ultimately the Bolsheviks did "get" him, spiriting him out of France to Russia in 1938, where he was executed on 11 May $1939 . .^{51}$

As to the two icebreakers which had engaged in a truly unique historical moment, Kanada and Minin, the former remained in Soviet hands and, re-named Fedor Litke, became the "grandfather" of the Soviet ice-breaking fleet, scoring many firsts in Arctic exploration, working in Arctic waters and ice until 1959.52 Minin, in 1920, remained berthed in an English port under the control of the Russian Committee, which held the ship for Baron Wrangel's White forces in the Crimea. ${ }^{53}$ After the collapse of Wrangel's armies later in that year, the ship ended up in French hands, docked at Cherbourg. It was offered for sale to the Canadian government at the same time that Ottawa was negotiating with France in1921-1922 for Mikula Selianinovich, ex-Canadian J.D. Hazen. Canada bought back Mikula but declined the offer of Minin. ${ }^{54}$ Minin was soon despatched to Bizerte, in Tunisia, to join the

\footnotetext{
49 There is ongoing debate about responsibility for the botched evacuation which abandoned masses of White officers and their families. Some sources suggest that it was Admiral Vil'kitsky, who had been charged with effecting the evacuation and took charge of Minin as ship's master as the icebreaker departed Archangel, who botched the operation. Perhaps it is fairer to say that most of the White command in the Russian North bore shared responsibility for the evacuation debacle. (https.// rusidea.org/25051109).

50 Where Wrangel had planned ahead to save his people, and approximately 150,000 were evacuated from the peninsula as the possibility of holding on in Crimea disappeared, Miller had failed to plan ahead, misread the signs of collapse, held to the quixotic notion of standing fast, squandered the resources at hand to organize an evacuation (the icebreakers and ice capable steamers) and, most shamefully as many maintained, had deserted his forces in the field, many of whom, especially the officers, were executed en masse, perhaps as many as 6,000.

51 A.F.Kiselev, ed., Politicheskaia istoriia Russkoi emigratsii 1920-1940 gg. Dokumenty i materialy [Political History of the Russian Emigration 1920-1940. Documents and Materials], (Moscow: Gumanitarnyi Izdatel'skii Tsentr [Humanities Centre Publisher]), 1999, 57-61.

52 See W. Barr's unpublished manuscript "Half a Century of Icebreaking. Earl Grey alias Fedor Litke, 1909-1959," LAC, Department of Transport, RG 12, Vol. 3855, File 11. Once broken up in the late 1950s her wheel-house was saved, and is on display in a major Russian maritime museum in Moscow.

53 O. Parkes and M. Prendergast, Jane's Fighting Ships 1920, (London and Edinburgh: Sampson, Low, Marston and Company, 1920), 570.

54 LAC, Department of Foreign Affairs, RG 25, Vol 1279, File 1443. The French, for some peculiar reason, began to title the ship Minim(e), and this mis-spelling is reflected in Canadian-French government correspondence, as well as in Jane's.
} 


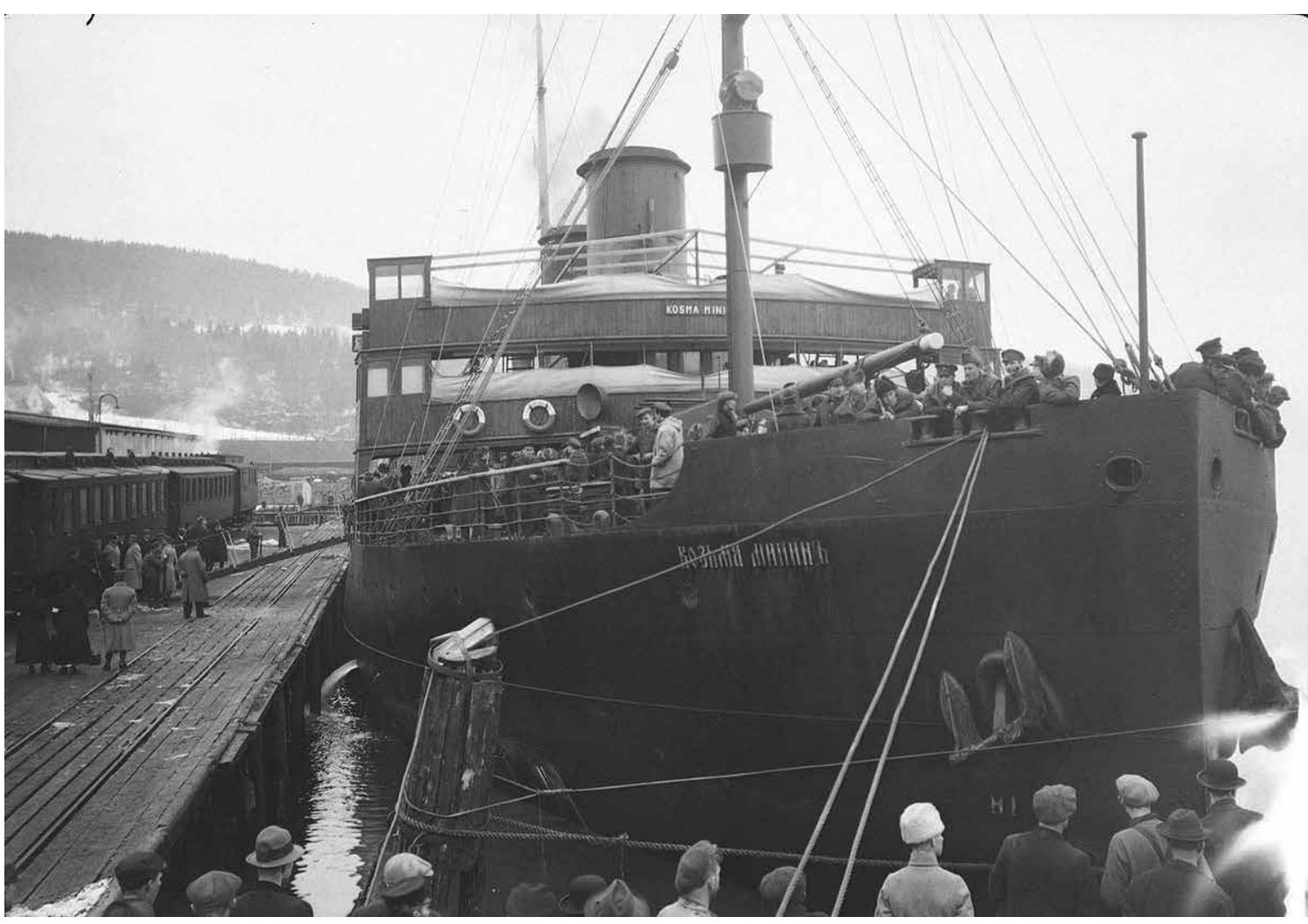

The Ice-Breaker Koz'ma Minin, Refugees De-Barking in Tromso, Norway (vaga-land.livejournal.com $>1015857 . \mathrm{html}$ )

remnants of the Imperial Russian fleet interned at that port, ${ }^{55}$ the vessels which had steamed away from the Crimea evacuating Baron Wrangel's White forces and their families, as well as other civilians. Unable to sell the vessel, the French inducted Minin into their fleet, refitting it as a minelayer renamed Castor. ${ }^{56}$

One wonders whether or not her French crew were cognizant of their ship's past, that they sailed a unique ship which had participated in a near-epic flight

55 Parkes and Prendergast, Jane's Fighting Ships 1920, 320. Minin, renamed Castor, served in the French fleet until it was seized by the Germans in 1942, later sunk, and raised in 1946 . Too expensive to restore, it was broken up soon after ("Sbezhavshyi ledokol 'Koz'ma Minin'," [“"Koz'ma Minin',The Icebreaker Which Escaped”] zen.yandex.ru>Iandex.Dzen>...ledokol..kozma-minin)

56 The French did likewise with Ilia Muromets, another former Russian icebreaker of similar dimensions as Koz'ma Mnin, also making it over into a mine-layer, and re-naming the ship Pollux. Thus, the two ships were twinned. Pollux, at the commencement of the Second World War, laid mines in the North Sea and the English Channel, becoming a training vessel in the British Fleet in 1940. It returned to France in 1946, served as a pontoon vessel and was broken up in 1956 (V.G. Andrienko, “Ledokol'nyi flot Rossii, 1860-e-1918gg. [The Icebreaker Fleet of Russia 1860-1918] Glava 6. [Chapter 6] Sud'by severnykh ledovykh sudov [The Fates of Northern Ice Ships]," military. wickireading.ru>31453). 
allowing more than one thousand people to escape near-certain death, a ship which had fought in an engagement never seen before nor since - two armed icebreakers in northern Arctic ice, only several kilometres south of the Arctic Circle, firing their guns at each other in anger. 